\title{
"BIZARRIA DE ENGENHO": SILVA ALVARENGA E O POEMA HERÓI-CÔMICO NA DOUTRINA DE FRANCISCO JOSÉ FREIRE
}

\section{"BIZARRIA DE ENGENHO": SILVA ALVARENGA AND THE HERO- COMIC POEM IN THE DOCTRINE OF FRANCISCO JOSÉ FREIRE}

\author{
Samuel Carlos MELO ${ }^{1}$ \\ Tiago de Jesus VIEIRA ${ }^{2}$
}

\begin{abstract}
Resumo: Este artigo tem como objetivo efetuar análise de "Discurso sobre o poema herói-cômico", texto que antecede $O$ Desertor (1774), poema herói-cômico de Silva Alvarenga. Nesse texto, o poeta luso-brasileiro tenta justificar a opção pelo gênero herói-cômico diante da rejeição dos críticos. São escassos os estudos históricos e críticos de fôlego sobre a obra e, dentre os que tratam diretamente do poema, com algumas exceções, têm-se leituras ainda insuficientes e uma recepção desinteressada, fato que contrasta com a fortuna de Glaura (1801). Sendo assim, faz-se necessário tentar compreender a produção poética de Silva Alvarenga diante das convenções poéticas e retóricas que orientaram as letras no século XVIII. O principal referencial em língua portuguesa desse período é Arte Poética (1748/49), de Francisco José Freire. Pretende-se estabelecer um cotejo entre os pressupostos sobre a natureza do poema herói-cômico expostos por Alvarenga e os preceitos da doutrina poética de Freire, a fim de contribuir para a ampliação dos estudos sobre $O$ Desertor. Para isso, além dos textos já mencionados de Freire e Alvarenga, este artigo se apoiará nas leituras de Aristóteles (1984), Candido (1975) e Genette (1971), e Ivan Teixeira (1999).
\end{abstract}

Palavras-chave: Poesia colonial. Épico. Cômico. Setecentos. Período pombalino.

Abstract: This paper aims to analyze "Discurso sobre o poema herói-cômico [Discourse on the herocomic poem]", a text that precedes $O$ Desertor [The Deserter] (1774), a hero-comic poem by Silva Alvarenga. In this text, the Luso-Brazilian poet tries to justify his choice for the hero-comic genre in face of the critics' rejection. Historical and critical studies on the work are scarce and, among those that deal directly with the poem, with some exceptions, there are still insufficient readings and a disinterested reception, a fact that contrasts with reviews of Glaura (1801). Thus, it is necessary to try to understand the poetic production of Silva Alvarenga before the poetic and rhetorical conventions that guided the letters in the eighteenth century. The main reference in Portuguese language of this period is Poetic Art (1748/49), by Francisco José Freire. A comparison between the assumptions about the nature of the hero-comic poem expounded by Alvarenga and the precepts of Freire's poetic doctrine will be stablished in order to contribute to the expansion of studies on $O$ Desertor [The Deserter]. For this purpose, in addition to Freire and Alvarenga, this paper will be based on the readings of Aristotle (1984), Candido (1975) and Genette (1971), and Ivan Teixeira (1999).

Keywords: Colonial poetry. Epic. Comic. Seven hundred. Pombaline period.

\section{O Desertor}

O Desertor (1774) é um poema herói-cômico composto por 1.439 versos decassílabos heroicos brancos distribuídos em cinco cantos de estrofes irregulares. Narra a fuga de Gonçalo

\footnotetext{
${ }^{1}$ Doutorando em Literatura Brasileira pela USP, docente de Teoria Literária e Literaturas de Língua Portuguesa da UEG, Campus Iporá. samuel.melo@ueg.br

${ }^{2}$ Tiago de Jesus VIEIRA: Doutor em História pela UFMT, docente de História Moderna e Contemporânea da UEG, Campus Iporá. tiago.vieira@ueg.br 
para abandonar os estudos na Universidade de Coimbra, após ser convencido pela Ignorância (alegoria à resistência à reforma do Marquês de Pombal). Somado a Ode à Mocidade Portuguesa por Ocasião da Reforma da Universidade de Coimbra e Ao Ilustríssimo e Excelentíssimo/Sebastião José de Carvalho/Marquês de Pombal, etc. Ode., O Desertor forma o conjunto de poemas pombalinos escritos pelo autor.

São escassos os estudos históricos e críticos de fôlego sobre $O$ Desertor, destacando-se o empreendimento de Ronald Polito, que reuniu a fortuna crítica e documental da obra, disponibilizada na edição de 2003, publicada pela editora da UNICAMP. Nela, observa-se, dentre as que tratam diretamente do poema, com algumas exceções, leituras ainda insuficientes e uma recepção desinteressada, fato que contrasta com a fortuna de Glaura (1801). Tal desprezo pelo poema herói-cômico e os demais poemas pombalinos de Silva Alvarenga, em detrimento de sua obra lírica, pode ser explicado pelo viés nacionalista da crítica, que buscou na poesia árcade traços que pudessem indicar, já no setecentos, o desenvolvimento de uma consciência nacional, a construção de um espírito de "brasilidade", em uma ótica de cunho romântico.

Sendo assim, faz-se necessário tentar compreender a produção poética de Silva Alvarenga diante das convenções poéticas e retóricas que orientaram as letras no século XVIII, considerando-a, ainda, dentro da conjuntura específica dos poetas luso-brasileiros do setecentos. A proposta deste artigo é partir dos pressupostos sobre o poema herói-cômico esboçados pelo próprio poeta no texto que antecede a obra, "Discurso sobre o poema heróicômico", no intuito de compreender o funcionamento da estrutura do poema em seu processo de representação.

\section{Doutrina poética}

“É preferível escolher o impossível verossímil do que o possível incrível”, observa Aristóteles (1984, p. 245) em sua Arte poética. Trata-se da teoria clássica da verossimilhança, cujo critério do juízo público é a base da ideia de convenção. Como esclarece Gerárd Genette, tem-se cada vez mais compreendido o verossímil como aquilo que as coisas "devem ser", estabelecendo uma oposição entre verdade e verossimilhança. Dentro dessa perspectiva, afirma o autor, a verdade seria, em sua singularidade, defeituosa, fazendo com que seja necessário buscar em princípios universais e nos modelos de verossimilhança os preceitos para a composição ficcional:

Na verdade, verossimilhança e conveniência confundem-se sob o mesmo critério, isto é, "tudo está de acordo com a opinião do público". Esta "opinião", real ou suposta, é bem precisamente o que se denominaria hoje uma ideologia, isto é, um corpo de Revista Graphos, vol. 21, n 2, 2019 | UFPB/PPGL | ISSN 1516-1536 
máximas e de preconceitos que constitui em seu todo uma visão de mundo e um sistema de valores (GENETTE, 1971, p. 9).

De acordo com Genette, portanto, o verossímil caracteriza-se pelo respeito à norma como um princípio formal, em que, implicitamente, determinada máxima geral aceita pelo público, orienta e explica o singular, como a conduta particular de um personagem, por exemplo. Nessa perspectiva, que é clássica, a originalidade seria uma extravagância restrita ao real, importando ao processo de composição responder ao corpo de máximas aceitas como reais, que, por sua vez, está estabelecido de forma implícita, em que "[...] as convenções de gênero funcionam como um sistema de forças e restrições naturais [...]", em um contrato entre obra e público, cuja verossimilhança é "[...] um significado sem significante, ou melhor, não há outro significante senão a própria obra" (GENETTE, 1971, p. 12-13).

Como já se disse, boa parte da escassa crítica de $O$ Desertor orientou-se pela perspectiva de cunho nacionalista, que aplicou à poesia luso-brasileira do século XVIII o critério de antecipação de um espírito de "brasilidade". No tocante aos poemas pombalinos, como consequência dessa ótica, tem-se ainda a tentativa de desvinculá-los de sua matriz ideológica, entendendo essa relação como uma deficiência poética. Soma-se a isso a dificuldade de compreensão dessa crítica de viés romântico pelo interesse poético da composição convencional nas letras do setecentos. Nesse sentido, para romper com esse reducionismo, fazse necessário tentar compreender como o processo de composição de $O$ Desertor, um poema herói-cômico, responde convencionalmente ao corpo de máximas que orientaram as letras portuguesas e luso-brasileiras do século XVIII, em seu contrato de verossimilhança com o juízo público.

O principal referencial da produção poética desse período foi Francisco José Freire (1749) e sua Arte poética, especialmente a segunda edição do texto. No prólogo de sua obra, Freire revela que uma das principais motivações para a elaboração de sua preceptiva foi a queixa de Luís António Verney, no Verdadeiro método de estudar, de que faltariam às letras portuguesas uma arte poética que, em sua língua, orientasse a composição dos novos poetas, fato que explicaria a ausência de bons poetas no país. O autor admite que, com exceção de alguns manuais de métrica e versificação, desconhece a existência de um texto impresso ou manuscrito que trate daquilo que é o poético em língua portuguesa.

Essa preocupação com a necessidade de uma poética em língua nacional pode ser compreendida ao se considerar o processo de divulgação da cultura antiga nos chamados 
“idiomas vulgares" que, como lembra Ivan Teixeira, tem sua consolidação a partir do século XVIII:

[...] a imitação dos antigos na arte e na ciência do século XVIII excede o propósito de repetir a Antiguidade por mera erudição, como, inadvertidamente, se poderia pensar hoje. Ao contrário, tratava-se de articular um enorme projeto de comunicação do saber ao homem comum, que não dominava as línguas clássicas (TEIXEIRA, 1999, p. 217).

O autor lembra ainda que Verney atuou para que a língua portuguesa fosse inserida nos currículos escolares de Portugal que, até aquele momento, centravam-se apenas no ensino da gramática do latim. Nesse sentido, com a ampliação do ensino da língua portuguesa e as traduções de obras clássicas no idioma nacional, seria possível ampliar a divulgação do conhecimento, o que favoreceria os planos doutrinários do Estado em alcançar um maior número de pessoas.

Ainda em seu prólogo, Francisco José Freire afirma que as regras que irá prescrever em sua poética têm como objetivo a utilidade e a instrução da mocidade portuguesa, elaboradas conforme a razão e as autoridades clássicas. O ponto de partida adotado por Freire em sua Arte Poética é o princípio horaciano de uma poesia dulce et utile, e o que se verificará nos três livros que compõem a preceptiva, portanto, são orientações de cunho formal e, principalmente, utilitário. A obra configura-se como uma espécie de manual rígido para os novos poetas que, como também observou Ivan Teixeira, derivou-se diretamente de La Poética, de Luzán, e que não tinha o intuito de fornecer uma teoria original:

Como era costume, Freire parecia mais empenhado em compendiar noções atualizadas para a formação poética dos jovens de seu país do que propriamente em criar uma teoria poética. Adotou a postura de quem organiza um compêndio didático, bem caracterizado e sem muita pretensão à novidade (TEIXEIRA, 1999, p. 214).

Essa atualização, calcada também em fundamentos do cristianismo, desempenhou um papel de cunho essencialmente pedagógico nas letras portuguesas, pois, como relata Teixeira, diferente da Della Perfetta Poesia Italiana, de Muratori, cujas ideias já poderiam ser encontradas anteriormente na prática dos poetas italianos, a obra de Freire tinha como alvo um público ainda inexperiente em língua portuguesa com as proposições de seu compêndio, considerando a predominância do estilo agudo seiscentista nas primeiras quatro décadas do século XVIII em Portugal.

Diante disso, considerando o já mencionado papel central da Arte Poética no contexto da propagação do ideário pombalino, faz-se necessário abordar alguns conceitos essenciais que constituem as funções de utilidade e deleite da doutrina de Francisco José Freire. No que diz 
respeito ao aspecto utilitário da produção poética, deve-se destacar a segunda edição da Arte Poética, publicada em 1749, cuja dedicatória, especificamente, exerceu um papel fundamental na instrução dos novos poetas daquele período quanto à matéria central de seus versos, convocando-os à necessidade de aderirem a uma nova tópica:

[...] para ficar mais provado, que ainda quando uma indispensável obrigação me não inspirasse o consagrar a V. Excelência esta Obra, o ser ela uma Arte Poética, estava pedindo que eu a enobrecesse com seu ilustre nome, afim de que nela não faltassem nem os preceitos, nem o Herói: formem-se os Poetas; que para a Épica, e Lírica tem eles em V. Excelência um Argumento tão vasto, como glorioso (FREIRE, 1749, n.p).

O herói e argumento propostos por Francisco José Freire aos novos poetas era o ainda ministro Sebastião José de Carvalho e Mello. Ao iniciar seu agradecimento, Freire destaca a generosidade de Sebastião José como mecenas de mais uma obra sua (já havia financiado a sua tradução de Arte Poética, de Horácio), ressaltando a necessidade de agradecê-lo pelo gesto de grandeza em "patrocinar aos pequenos", bondade que, para ele, assemelhava-se à da "Divindade suprema". Segundo o autor, apenas o fato de o ministro ter, em seus "anos florentes", cultivado com distinção a "ciência poética" já seria o suficiente para se considerar natural o oferecimento de sua obra. Porém, afirma ele, embora a prática da poesia na juventude já o colocasse como a "glória das Musas", Sebastião José teria vindo ao mundo para coisas maiores, “[...] mais para dar matéria à Poesia, que para cultivar seus preceitos” (FREIRE, 1749, n.p). Sendo assim, arremata Freire, ao dedicar sua Arte Poética ao ministro, sua intenção foi a de apresentar aos jovens poetas, ao mesmo tempo, preceitos sólidos e o "[...] verdadeiro Assunto para os seus versos" (FREIRE, 1749, n.p).

Freire ainda traz uma lista das virtudes que, segundo ele, constituem o ministro como o "Herói das Musas Lusitanas": a sua preferência pelo trabalho ao descanso, “[...] um Espírito de ânimo e constância incrível [...]"(FREIRE, 1749, n.p), alguém que, embora cauteloso em suas ações, não despreza as oportunidades dadas pela sorte em prol da felicidade pública, que é capaz de "[...] conciliar a urbanidade com o respeito, a severidade com a doçura [...]”(FREIRE, 1749, n.p), uma pessoa fiel às promessas e "honradora dos bons". Além disso, destaca ainda o seu êxito nas ações em prol do comércio português, das fábricas manufatureiras, a criação de "leis santíssimas", a reconstrução de Lisboa e o triunfo do rei “[...] de um execrando atentado contra sua preciosa vida, só com fazer executar seus reais decretos" (FREIRE, 1749, n.p).

Conforme a hipótese de Ivan Teixeira, a Arte Poética de Freire foi uma das peças centrais do projeto de propagação do ideário pombalino, combatendo a neoescolástica jesuítica, especialmente com a proposta da dedicatória da segunda edição que sugere a incorporação de 
Pombal como matéria da poesia, o que concederia, na perspectiva de Freire, atualidade e, principalmente, utilidade aos versos dos poetas iniciantes.

De acordo com Teixeira, é possível observar em O Uraguay que as premissas que constituem a doutrina poética de Francisco José Freire foram acolhidas por Basílio da Gama:

[...] o poema de Basílio pode ser lido como uma resposta ao apelo da poética de Freire, muito enfática na proposição de Pombal como grande assunto para os poetas emergentes, assunto que, na perspectiva do retor, conferia não só atualidade, mas também utilidade à poesia para a qual sua poética lançava as bases (TEIXEIRA, 1999, p. 74).

O autor destaca ainda que essa dedicatória fora elaborada conforme os preceitos do panegírico clássico, cuja argumentação da glorificação se constrói com o objetivo de, também, instruir os indivíduos de esferas sociais inferiores por meio de exemplos de ações e modelos de boa conduta civil. Segundo o autor, o que se vê na dedicatória da segunda edição da Arte Poética, embora seja evidente o apoio à governança pombalina, nada mais é que a particularização da tópica do bom governo, um apelo com o intuito de que a nova poesia fosse útil para a consolidação da ordem monárquica.

Segundo Ivan Teixeira (1999), a ideia de que a dedicatória da obra de Freire tenha desempenhado um papel genuíno de manifesto, considerando a compreensão atual de "um programa coletivo de conduta poética", decorre dos diversos poemas exaltando a figura de Sebastião José de Carvalho surgidos após a publicação da dedicatória, apontando que, especialmente quanto ao tema proposto, o "[...] apelo foi atendido com entusiasmo pelos poetas do período, tanto os brasileiros quanto os portugueses" (TEIXEIRA, 1999, p. 74).

Essa compreensão do papel utilitário da poesia é desenvolvida por Francisco José Freire, especialmente, no capítulo 4 do primeiro livro de sua Arte Poética, em que discute "O fím da Poesia”. Segundo o autor, não há dúvida de que o principal fim da poesia seja ensinar o povo, "servi-lhe de utilidade", empenho que, segundo ele, já se pode ver nos primeiros poetas, como Hesíodo e Homero. Entretanto, Freire observa que, embora todos os poemas devam ser úteis para quem os ouve ou lê, alguns foram designados pela Política, ou Filosofia Moral, com o intuito de instruir pessoas específicas, como no caso dos capitães e guerreiros, que poderiam encontrar nos poemas heroicos exemplos ilustres de ações grandiosas e do amor à glória. Para o autor (TEIXEIRA, 1999, p. 26-27), a poesia não seria mais que “[...] uma Filosofia moral vestida com mais pompa, e galhardia" e, recorrendo a Horácio, afirma que os Poetas teriam sido "[...] os primeiros legisladores de costumes, e os primeiros Sábios, e Filósofos da antiguidade, ensinando, e instruindo os povos com a Filosofia Moral [...]”. 
O vínculo entre o conceito de filosofia moral e poesia perpassa toda a Arte Poética de Freire, como se pode observar já no primeiro capítulo do primeiro livro, em que o autor afirma que ambas são "[...] uma mesma coisa, ainda que expressa com dois diferentes nomes" (TEIXEIRA, 1999, p. 11). Conforme observa Ivan Teixeira (1999, p. 212; 256), Francisco José Freire compreendia a filosofia moral como um conceito concernente à ética do Antigo Regime, sendo a poesia uma espécie de dispositivo do aparelho de Estado, em termos atuais, cuja função central seria "[...] o auxílio ao governo dos povos, reforçando os princípios da religião, ratificando a autoridade dos reis e justificando a obediência geral ao Estado e à Igreja" (TEIXEIRA, 1999, p. 212). Como se sabe, naquele período, Estado e Igreja determinavam a compreensão sobre a concepção de virtude e de vício, engendrando o entendimento filosófico que permitiria se chegar à verdadeira felicidade, por meio da demonstração da " [...] essência da virtude e os deveres do homem que desejasse se orientar pela boa razão" (TEIXEIRA, 1999, p. 256).

Nessa mesma perspectiva, está o entendimento sobre a função de deleite da poesia. De acordo com Freire (1749, p. 54), o deleite poético consiste no "[...] prazer, e gosto, que recebe nossa alma pela beleza, e doçura da Poesia”, o que faria com que ela fosse maior que as demais ciências e artes. A beleza, por sua vez, seria a luz responsável por fazer brilhar a verdade, luz essa que não consistiria em “[...] outra coisa senão a brevidade ou a clareza, a energia, a utilidade e outras circunstâncias que podem acompanhar e fazer bela a verdade [...]" (FREIRE, 1949, p. 54).

Para Freire, enquanto "arte fabricante", a poesia pode provocar o deleite de dois modos: com a verdade que imita, sendo ela nova e maravilhosa em si mesma, ou com a maneira de a imitar, em que o poeta extrai da matéria a novidade por meio de seu artifício ao representá-la. Segundo o autor, as verdades novas e maravilhosas são a origem do deleite e constituem a alma da poesia, pois, se não há novidade, também não se pode obter o maravilhoso e, como consequência, a poesia "[...] não nos instrui, pois sempre tiramos nossa instrução de alguma coisa, que seja nova" (FREIRE, 1749, p. 55). Ele adverte, porém, que é impossível que o poeta encontre sempre verdades admiráveis e novas em si para imitar, cabendo ao seu artifício revestir a matéria trivial de "vivas cores" que a torne admirável. De acordo com o autor luso, há ainda a possibilidade de se unir uma matéria em si nova com o artifício poético, o que ampliaria a sua novidade, tornando-a capaz de um deleite muito maior.

Francisco José Freire (1749) afirma ser necessário que os poetas imitem os objetos não da maneira como foram produzidos pela natureza, mas de forma verossímil, representando-os 
como podem ou deveriam ser. Segundo o autor, o poeta deve "[...] completar, e aperfeiçoar a natureza" (FREIRE, 1749, p. 66), descobrir na matéria aquilo que é raro e maravilhoso, representando-a mais do que ela é ordinariamente. Nesse sentido, o "verdadeiro da natureza" se distingue em duas espécies: o verdadeiro que é ou foi e o verossimilmente verdadeiro:

\begin{abstract}
O primeiro verdadeiro buscam os Teólogos, os Matemáticos, os Historiadores, e outras ciências. O segundo pertence aos Poetas, que são os que principalmente o buscam. Do conhecimento do primeiro vem a ciência, e do segundo, a opinião. Um pode-se chamar verdadeiro, necessário, ou evidente, ou moralmente certo [...]. Outro pode-se chamar verdadeiro, possível, provável, e crívei, que vulgarmente se diz verosímil [...] (FREIRE, 1749, p. 72).
\end{abstract}

Segundo Freire, embora a busca pelo verdadeiro certo e evidente seja muito difícil, o que faz com que se contente e se deleite com o verossímil, são inúmeros os poemas em que se pode encontrar muito do que verdadeiramente foi ou realmente é, em que figuram pedaços da História, Geografia e outras ciências. As invenções poéticas, afirma ele, devem sempre ter como fundamento uma dessas espécies de verdadeiro, sob o risco de não alcançarem a beleza, caso não possibilitem a apreensão de alguma verdade, mesmo que o poeta encontre algo novo e maravilhoso, pois, o falso, como algo impossível, incrível e inverossímil, causaria um grande descontentamento. Sendo assim, o bom poeta é aquele que sempre representará coisas verdadeiramente certas e existentes ou aquelas que podiam, devem ou deveriam acontecer.

Segundo o autor, por mais que seja evidente que o verdadeiro possível de que deve se ocupar o poeta não seja o real, também não se pode afirmar que ele seja falso. O verossímil, observa ele, ocupa-se daquilo que verdadeiramente pode acontecer, de um fim possível e crível e que, por isso, é semelhante ao verdadeiro certo. Diante disso, afirma Francisco José Freire, o trabalho do poeta é capaz de possibilitar a compreensão de uma verdade ainda desconhecida, da qual se pode obter uma "opinião".

Nesse sentido, Ivan Teixeira (1999, p. 225) observa que é possível distinguir duas áreas de referência na noção de verdade do plano doutrinário de Francisco José Freire: a ética e a poética. De acordo com o autor, no âmbito do poético, a verdade consiste em uma adequação da escolha da matéria com as recomendações do costume, como o gênero, espécie, estilo e ornatos, relacionados à brevidade, clareza e energia. Já do ponto de vista ético, a verdade consistiria em um “[...] ajustamento da perspectiva política do poeta com os preceitos sancionados pela tradição social”, relacionado à utilidade, como detalha Freire no quarto capítulo de sua Arte Poética: 


\begin{abstract}
A Poesia considerada em si mesma procura causar seu deleite, e considerada como Arte sujeita à faculdade civil toda se emprega em causar utilidade. E como quer que esta tal faculdade seja a que encaminha todas as Ciências, e Artes à felicidade eterna, atemporal, e ao bom governo dos povos, por isto a verdadeira, e perfeita Poesia deveria sempre igualmente deleitar, que utilizar a uma República. Quem com a boa imitação Poética não deleita, peca propriamente contra uma intenção da Poesia; e quem imitando, e deleitando, não é igualmente causa de que o povo se aproveite, e se instrua, peca gravemente contra outra precisa obrigação desta Arte [...] (FREIRE, 1749 , p. 29-30).
\end{abstract}

Observe-se, portanto, que, subordinadas à filosofia moral, essas áreas são indissociáveis na doutrina poética de Francisco José Freire, devendo a "perfeita Poesia" empregá-las igualmente. Sendo assim, primeiramente, cabe a este estudo tentar compreender o poema heróicômico de Silva Alvarenga por meio dessas duas áreas basilares para a poesia do período, iniciando pela tentativa de recuperação histórica de alguns pontos relevantes que compõem a matriz ideológica de $O$ Desertor e, em seguida, no âmbito poético, discutir a adequação do gênero à matéria, conforme as recomendações do costume.

No tocante à poesia como arte sujeita à faculdade civil, parecem ser suficientes os dados da historiografia que apontam para a adequação de $O$ Desertor a essa função da poesia na doutrina de Francisco José Freire. Para além do próprio argumento do poema, as informações que indicam a participação de Silva Alvarenga no sistema de propagação do ideário pombalino por meio de grupo de poetas luso-brasileiros, liderado por Basílio da Gama e a própria edição da obra, impressa pela Universidade de Coimbra sob o financiamento do ministro, demonstram que o poema herói-cômico correspondeu à obrigação ética da arte naquele contexto.

De acordo com Ivan Teixeira (1999), Basílio teria sido o responsável por apresentar pessoalmente Alvarenga ao Marquês de Pombal. Segundo ele, embora não se tenha documentação precisa sobre esse encontro, essa hipótese mostra-se verossímil ao se considerar a sua já referida proximidade com Basílio da Gama e a representatividade deste junto ao ministro. Joaquim Norberto de Souza e Silva confirma essa tese e relata que o poema "Ode à Mocidade Portuguesa por Ocasião da Reforma da Universidade de Coimbra”, escrito em 1772, teria sido o elemento responsável por despertar o interesse de Sebastião José pelo lusobrasileiro:

Entusiasmou-se Silva Alvarenga com a nova época que despontava para as letras, e seu estro acendeu-se para celebrar-lhe os triunfos. Saudou a mocidade portuguesa, a quem se abriam de novo as portas do templo das ciências, sem que se esquecesse da mocidade brasileira. Leu o marquês de Pombal essa bela ode, e para logo desejou conhecer pessoalmente o jovem poeta (SOUZA e SILVA, 1864, p. 38). 
Ainda de acordo com o autor, durante esse encontro, Sebastião José teria proferido palavras motivadoras ao jovem poeta, e esse gesto de acolhimento prestado pelo ministro teria sido fundamental para que Silva Alvarenga idealizasse e se empenhasse na composição de $O$ Desertor. Em 1774, o poema herói-cômico foi impresso pela Imprensa da Universidade de Coimbra, em edição financiada por ordem do ministro, segundo o relato de Joaquim Norberto. A publicação da obra e o empenho de Basílio da Gama foram determinantes para a sua consolidação no círculo de propagação do ideário pombalino.

Considerando a indissociabilidade dessas áreas, é necessário observar como se realiza a dimensão poética em $O$ Desertor, como se dá a adequação da matéria aos elementos prescritos pelo costume, também referenciados pelo plano doutrinário de Francisco José Freire. Nesse intuito, é imprescindível analisar o texto que antecede a obra, denominado "Discurso sobre o poema herói-cômico", em que, ao tentar justificar a escolha do gênero, Silva Alvarenga discorre sobre sua perspectiva sobre a poesia.

\section{Engenho bizarro}

Silva Alvarenga (2003) inicia a sua justificativa com destaque para o conceito de imitação. Segundo o poeta, a imitação da Natureza é a grande força da Poesia, pois se trata do "[...] meio mais eficaz para mover, e deleitar os homens; porque estes têm um inato amor à imitação, harmonia, e ritmo" (ALVARENGA, 2003, p. 71). A definição de Alvarenga está calcada no capítulo quatro da Arte Poética, de Aristóteles, em que se discute a origem da poesia e seus diferentes gêneros. De acordo com o filósofo grego, a aptidão para imitação é inerente ao homem desde a infância, fator que o distingue das demais espécies. É por meio da imitação, afirma ele, que o homem adquire os primeiros conhecimentos e em que todos experimentam o prazer:

\footnotetext{
A prova é-nos visivelmente fornecida pelos fatos: objetos reais que não conseguimos olhar sem custo, contemplamo-los com satisfação em suas representações mais exatas. Tal é, por exemplo, o caso dos mais repugnantes animais e dos cadáveres. [...] Os seres humanos sentem prazer em olhar para as imagens que reproduzem objetos. A contemplação delas os instrui, e os induz a discorrer sobre cada uma, ou a discernir nas imagens as pessoas deste ou daquele sujeito conhecido.[...] Como nos é natural a tendência à imitação, bem como o gosto da harmonia e do ritmo (pois é evidente que os metros são parte do ritmo), nas primeiras idades os homens mais aptos por natureza para estes exercícios foram aos poucos criando a poesia, por meio de ensaios improvisados (ARISTÓTELES, 1983, p. 244).
}

Conforme observou Antonio Candido (1975), o conceito de imitação adquire no setecentos um sentido próprio, decorrência de uma consciência integradora que busca ajustar a 
ordem natural com a ordem da criação ficcional e social. Para os poetas desse período, o processo de imitação de formas naturais da realidade se dá não só por meio da razão, mas também a partir do acesso a uma espécie de “[...] arquivo da natureza, formado pelos antigos e funcionando, por assim dizer, como natureza de segundo grau, recriada mediante a imitação literária, que dava à obra segurança e nobreza, dando-lhe genealogia estética" (CANDIDO, 1975, p. 49-50). Dessa forma, a imitação da ação se dá na afirmação de valores, no caso, aqueles em voga nos setecentos, e pela emulação de modelos em sua composição estrutural, pois, “imitar Virgílio, é não apenas participar, por exemplo, da ordem de valores criada por ele, mas também assegurar instrumento literário já verificado no trabalho de criação. A conformidade com o modelo é o orgulho do escritor neoclássico [...]" (CANDIDO, 1975, p. 49-50).

A excelência dos modelos, afirma Candido (1975), é comprovada pela admiração constante e antiga dos receptores, o que forneceu à teoria do Arcadismo outros apoios. De um lado, o uso de elementos da educação humanística como meio para a emoção, solidificados na consciência do homem culto (o mito, a lenda e a história antiga), ofereceu um recurso de despersonalização do lirismo, numa caixa de ressonância em que uma linguagem universal formada pelo acervo tradicional da Antiguidade fornecia “" [...] apoio à imaginação do criador e do receptor de literatura, como sistema de formas através do qual dava sentido à experiência humana" (CANDIDO, 1975, p. 50). Por outro, no tocante à forma, a autoridade da tradição na prescrição de regras minora o arbítrio do poeta, pois, entendidas como manifestação da ordem natural, as regras deveriam ser conservadas, criando, assim, “[...] pontos de referência para o homem medianamente culto, propiciando e reforçando a comunicabilidade" (CANDIDO, 1975, p. 50).

Em consonância com o conceito aristotélico de imitação, Silva Alvarenga prossegue o seu discurso, destacando a necessidade de que o poeta tenha habilidade para escolher ações para imitar que conduzam ao fim desejado conforme o gênero. Nesse sentido, o épico deve trazer ações que inspiram admiração e amor pela virtude, em que apareçam a piedade, a prudência, o amor pela pátria, o respeito pelas leis e a veneração pelos príncipes; o trágico, no intuito de causar terror e compaixão, traz ações que provoquem horror do crime, apresentando o temor, o desespero e a dimensão do castigo; e o cômico, para combater os vícios, imitará ações vulgares que provocam o riso.

Para o poeta luso-brasileiro, embora seja difícil precisar qual dessas imitações atinge mais rapidamente o seu fim, “[...] quase sempre o coração humano, regido pelas leis de seu amor próprio, é mais fácil em ouvir a censura dos vícios, do que o louvor das virtudes alheias" 
(ALVARENGA, 2003, p. 72). No seu entendimento, portanto, as ações imitadas pelo cômico apresentam resultados mais imediatos para a instrução dos homens que os demais gêneros. Após isso, o poeta passa a discutir o estatuto do poema herói-cômico e a recepção dos críticos, indicando compreendê-lo como uma espécie do gênero cômico.

Segundo Silva Alvarenga (2003), por ser a imitação de uma ação cômica tratada heroicamente, o poema herói-cômico foi recebido por críticos "mais escrupulosos" como monstruoso. Para esses críticos, segundo o poeta, por ser o poema herói-cômico uma espécie que abraça, simultaneamente, duas espécies de poesia, não seria possível "assinar seu verdadeiro caráter", o que, para ele, seria uma interpretação equivocada dos diálogos da República, de Platão.

No terceiro livro da República, em determinado momento dos diálogos entre Sócrates e Adimanto, surge a dúvida sobre a possibilidade de que um mesmo homem possa imitar várias coisas perfeitamente. Sócrates, então, argumenta que, assim como para uma pessoa só é possível exibir talento em apenas uma profissão, não é possível executar de forma exitosa, ao mesmo tempo, dois tipos de imitação, pois aquele que tentasse obter êxito em mais de uma, em nenhuma alcançaria a fama:

\footnotetext{
Sócrates - Portanto, dificilmente exercerá ao mesmo tempo uma profissão importante e imitará muitas coisas e será imitador, uma vez que as mesmas pessoas não podem executar bem dois tipos de imitação que parecem próximos um do outro, como a tragédia e a comédia. Tu não dizias que eram ambas imitações?

Adimanto - Sim, e dizes a verdade: as mesmas pessoas não podem triunfar nos dois gêneros.

Sócrates - Nem é possível ser, simultaneamente, rapsodo e ator.

Adimanto — Estou de acordo (PLATÃO, 1993, p. 119).
}

Alvarenga (2003) argumenta que essa incompatibilidade entre duas imitações distintas de que tratam os diálogos se refere, especificamente, à impossibilidade de autores trágicos e cômicos serem perfeitos na realização de ambos os gêneros, o que tornaria infundada e pueril a crítica ao poema herói-cômico, "[...] pois a mistura do heroico, e do cômico não envolve contradição, que se acha na Tragicomédia, onde o terror, e o riso mutuamente se destroem" (ALVARENGA, 2003, p. 72).

A argumentação de Silva Alvarenga é também uma reação à censura que faz Francisco José Freire na Arte Poética. No segundo livro de sua doutrina, Freire critica a contrariedade da tragicomédia, considerando-a um "[...] monstro na Poesia tão enorme, e contrafeito, que podem os Centauros, e as Quimeras parecerem uns partos perfeitos da natureza" (FREIRE, 1749, p. 150). Para o autor português, na esteira do pensamento platônico, não é possível que um mesmo 
indivíduo represente, ao mesmo tempo, ações contrárias, assim como também não é possível que da representação de dois vícios possa surgir alguma virtude.

Segundo Freire, a tragicomédia é um composto poético monstruoso criado por alguns autores no intuito de desprezar a Poesia. $\mathrm{O}$ autor é taxativo quanto à possibilidade de se formar um sujeito poético por meio da união de duas espécies de poesia tão contrárias entre si:

\begin{abstract}
[...] assim como um Príncipe em uma mesma pessoa não pode ser realmente Príncipe, e Cidadão particular, assim igualmente é impossível, que a Tragédia, sendo imitadora de Príncipes, possa fazer um só individuo junto com a Comédia, representando esta gente particular. Não pode ser, segundo a natureza, que na Tragicomédia se faça, com que as pessoas Reais, e plebeias tenham um mesmo caráter, e lugar; que nela caiba o estilo grave, e o humilde; e que a graciosidade de ditos, e fatos se una com a veneração das pessoas, e com a severidade dos costumes [...] (FREIRE, 1749, p. 152).
\end{abstract}

Segundo o autor, a Comédia e a Tragédia seriam espécies de poesia completamente perfeitas, tanto na teoria quanto na prática. Para ele, acreditar que delas seja possível a composição de um misto perfeito seria o mesmo que crer "[...] que do mel, e do fel se pode fazer um misto potável, gostoso ao paladar, e que em uma República política se podem congregar os homens, e os animais, e viver entre si com boa harmonia" (FREIRE, 1749, p. 154). Freire ironiza aqueles que defendem essa possibilidade, afirmando que, para esses "bons autores", um poema formado pela Bucólica e pela Eneida seria concebido como uma bela harmonia poética, sendo intitulado por eles como "bucoleroico".

Embora essas críticas sejam direcionadas especificamente ao modo de composição da tragicomédia, no início do terceiro livro de sua doutrina poética, ao tratar da natureza e definição do poema épico, Francisco José Freire traz uma posição semelhante ao alertar para a necessidade de que a ação da epopeia seja exclusivamente de caráter heroico:

[...] não há de ser a expugnação de um Castello arruinado, em que viviam Gralhas, como fez Zipoli no seu Malmantile racquistato; nem a conquista de um balde de pão, como o Poema de Tassoni, intitulado Secchia rapita; nem a questão entre certos Cônegos divididos em parcialidades sobre uma estante do seu coro, como fez Boileau no seu Lutrin; nem com a Troya rapita, formando-se de uma porca, que se furtou, e outros muitos Poemas deste gênero, que se compuseram por capricho, e bizarria do engenho (FREIRE, 1749, p. 168).

Se na junção do trágico e do cômico o autor sentencia a tragicomédia como sendo uma "poesia monstruosa", a mistura do cômico e do heroico na composição do poema herói-cômico é também rechaçada por Freire, classificada como fruto de "capricho" e "bizarria de engenho". Essa censura à mistura de duas espécies de poesia pode ser melhor compreendida ao se resgar 
o entendimento do autor quanto à ideia de "engenho", o que implica retomar também a compreensão de sua doutrina quanto ao conceito de imitação poética.

Em seu plano doutrinário, Francisco José Freire (1749), em consonância com a doutrina poética aristotélica, também compreende a imitação como parte da natureza humana. Para o autor, imitar poeticamente consiste na ação em que " [...] muitas vezes falando de tal modo, se veste uma coisa de imagens, e se exprime com pensamentos, ou belos, sensíveis, claros, novos, ou evidentes, que o entendimento a percebe sem trabalho [...]” (FREIRE, 1749, p. 30). Sendo assim, os objetos da imitação podem ser divididos em três mundos (ou reinos da natureza): o mundo celeste (superior), o mundo humano (mundo do meio) e o mundo material (inferior). Como mundo material, compreende-se tudo o que é formado por matéria ou corpo, como os corpos humanos, as flores e o Sol. O mundo celeste consiste naquilo que não tem corpo ou matéria, como Deus, anjos e as almas fora dos corpos. Por fim, o mundo humano abarca tudo que, ao mesmo tempo, é corpo e alma racional, ou seja, compreende todos os homens do mundo material.

Freire distingue a imitação em dois tipos: icástica e fantástica. De acordo com ele, a imitação icástica consiste na imitação do particular, tendo como objeto a verdade, representando “[...] todas ações, e coisas, que procedem da natureza, ou da Arte, e não menos da História, que da invenção de alguém" (FREIRE, 1749, p. 35). Já a imitação fantástica é a imitação do universal, sendo o seu objeto a ficção, ou seja, “[...] tudo o que não existindo por si, tem novo ser, e vida, nascendo da fantasia do Poeta, quando entra a inventar novas coisas, ou ações semelhantes às histórias, que se bem não sucederam, podiam suceder” (FREIRE, 1749, p. 35). $\mathrm{O}$ autor considera que todas as coisas dos três mundos podem ser objeto da poesia e, assim, entende que ambos os tipos de imitação podem ser admitidos.

De acordo com Ivan Teixeira (1999), ao contrário da imitação fantástica, que representa algo verossímil ou provável, ações que, embora possíveis, não foram confirmadas na prática, a imitação icástica aproxima-se da concepção aristotélica sobre a história, pois tem como objeto a verdade, representando determinada ação certa e ocorrida. Segundo o autor, tendo Platão como fundamento, “[...] a poética setecentista julgou que a imitação do particular não era exclusividade da história e passou a considerar que a poesia podia imitar tanto o universal quanto o particular" (TEIXEIRA, 1999, p. 249). Apesar disso, Teixeira observa que uma parte significativa da poesia desse período limitou-se à imitação icástica, reproduzindo eventos registrados pela crônica histórica portuguesa. 
Conforme a doutrina de Francisco José Freire (1749), os discursos poéticos formam-se a partir da captação e elaboração de imagens por meio de faculdades (ou potências) da alma. Também referida como "mente" e "cérebro", a alma seria composta por duas potências: a fantasia e o entendimento. A fantasia, denominada como "apreensiva inferior", por conta de sua localização na alma, teria como função apreender imagens dos objetos que se representam aos olhos e lançam "[...] um compêndio, uma imagem, uma semelhança de si mesmo, a qual, sendo recebida pelos sentidos, passa pelos nervos, e órgãos corpóreos, até que chega a imprimirse em nosso cérebro" (FREIRE,1749, p. 85). O entendimento, por sua vez, estaria na parte superior e racional da alma, sendo denominado como "apreensiva superior", cujo ofício seria o de estabelecer se são falsas ou verdadeiras as imagens obtidas pela fantasia:

Porém para meditar, e formar pensamentos, unem-se entre si estas duas potências, administrando a inferior à superior as imagens dos objetos, que lhe comunica sem se valer dos sentidos porque já em si as tem. Também pôde a potência inferior per si mesma valer-se destes objetos para imaginar as coisas já apreendidas, ou para fabricar outros objetos porque também ela tem força para conceber novas imagens (FREIRE, 1749, p. 86).

Segundo Freire, as imagens formam-se de três maneiras entre as faculdades da alma: pela ação racional do entendimento, sem relação com a fantasia; pela ação conjunta entre entendimento e fantasia; e pela fantasia, sem consulta ao entendimento. Na primeira, embora tenha apreendido as imagens, o entendimento as escolhe, julga e forma novas imagens. $\mathrm{Na}$ segunda, a fantasia expõe ao entendimento as imagens obtidas pelos sentidos, podendo formar outras novas, mas sempre tendo o entendimento como luz. A terceira consiste no domínio completo da alma pela fantasia, característica dos sonhos e febres, em uma completa ausência do entendimento.

Segundo o autor, enquanto não haveria lugar para a última na poesia, a segunda maneira seria a mais apropriada para o discurso poético. As imagens formadas pela união do entendimento com a fantasia são classificadas ainda em três grupos. No primeiro e no segundo grupo, as imagens são denominadas como simples e naturais, sendo as do primeiro diretamente verdadeiras à fantasia e ao entendimento, por pintarem as coisas como elas são e, as do segundo grupo, diretamente verossímeis à fantasia e ao entendimento, por pintarem as coisas como elas poderiam ser. No terceiro grupo, estão aquelas imagens que são diretamente verossímeis à fantasia e indiretamente verossímeis ao entendimento, denominadas como imagens artificiais fantásticas, pois “[...] devem o seu ser à fantasia, a qual une duas, ou mais imagens verdadeiras, 
e naturais, para formar uma nova, que nunca naturalmente houve, nem pôde haver, e parecer tal ao entendimento [...]” (FREIRE, 1749, p. 90).

Diante disso, o engenho configura-se como a "[...] virtude, e força ativa, com que o entendimento recolhe, une, e acha as semelhanças, as relações, e as razões das coisas" (FREIRE, 1749, p. 138-139). De acordo com Francisco José Freire, o engenho pode ainda ser classificado em dois modos: engenho agudo e engenho vasto. No primeiro modo, o entendimento penetra no interior das coisas a fim de compreender a sua natureza, razão e qualidade. Já no segundo, procura estabelecer as relações possíveis entre objetos diferentes e distantes entre si, buscando captar neles as semelhanças que os prendem.

Como observou Ivan Teixeira (1999), na doutrina poética de Freire, a fantasia capta isoladamente os elementos dos três mundos da imitação poética, cabendo ao engenho a função de estabelecer as relações entre eles, pois, embora nem sempre sejam visíveis, as relações existem e são inúmeras, resultando na expressão de diversos tipos de imagens. Dentre essas imagens, oriundas dos dois modos de engenho, Freire destaca três: as imagens de semelhança, as imagens de relação e as imagens de reflexão. As imagens de reflexão são formadas pelo engenho agudo, enquanto as imagens de semelhança e relação se formam no campo do engenho vasto.

Conforme define Francisco José Freire, as imagens de reflexão pertencem ao conjunto de imagens denominadas como intelectuais, pois são geradas pela busca das "razões internas das coisas", penetrando nos objetos em busca de se descobrir verdades neles:

[...] recolher, e descobrir as razões donde (se nós não enganamos) se argumenta a penetração, e agudeza do engenho de cada um. A este descobrimento das razões internas, e à consideração, ou contemplação, que faz o entendimento sobre as coisas, chamamos nós reflexão, vocábulo, que ignoraram os antigos, e percebem presentemente os modernos, por ser mui próprio, e acomodado a explicar estas contemplações do entendimento (FREIRE, 1749, p. 160).

As imagens de semelhança, por outro lado, podem ser classificadas como intelectuais ou fantásticas e são compostas por duas modalidades: as comparações e as metáforas. Ambas as modalidades partilham do princípio do engenho vasto de buscar semelhanças entre objetos díspares e distantes entre si, diferindo, porém, na relação entre entendimento e fantasia. Segundo Freire, as comparações podem ser classificadas como imagens intelectuais ou engenhosas, pois se formam em uma operação racional e clara que é própria do entendimento, sendo diretamente verdadeiras e verossímeis a ele. As metáforas, entretanto, são denominadas como imagens fantásticas, pois, por meio da fantasia, operam a transposição de características de um objeto para outro objeto semelhante: 
Destas coisas cada vez podemos ir aprendendo a diferença, que há entre as imagens fantásticas, e as intelectuais. Estas são diretamente verdadeiras, e tais parecem ao nosso entendimento; e aquelas diretamente são falsas ao entendimento, ainda que indiretamente ele as conheça por verdadeiras (FREIRE, 1749, p. 149).

Quanto à formação das imagens de relação, a operação seria o resultado de uma atuação conjunta entre fantasia e entendimento. Francisco José Freire compreende esse tipo de imagem gerado pelo engenho vasto como o estabelecimento de conexões entre um objeto e elementos que o circundam, de modo que a representação desses elementos possibilite que se identifique o objeto ao qual orbitam, dando dimensão de suas qualidades, por meio de uma relação de contiguidade. Como exemplo, o autor traz a figura de um grande e valoroso príncipe, cujas riquezas, as glórias do passado, os palácios, os súditos, as cidades, os soldados e, até mesmo, seus inimigos, dizem-lhe respeito e, assim, permitem o estabelecimento de imagens de relação.

Como se viu, localizado na parte superior e racional da alma, o entendimento é responsável por analisar se as imagens recebidas pela fantasia são falsas ou verdadeiras. Sendo assim, os discursos podem ser compostos por imagens formadas por meio da virtude racional do entendimento, sem consultar a fantasia, pela operação conjunta entre entendimento e fantasia, ou, ainda, somente pela fantasia, sem a regulação do entendimento:

\footnotetext{
A terceira maneira sucede, quando a fantasia domina absolutamente a alma, e pouco, ou nada atende para os conselhos do entendimento, como v. g. nos sonhos, nas febres, nos afeitos melancólicos etc. Esta terceira classe da fantasia não tem lugar algum na faculdade poética; porque a não regula o entendimento [...] (FREIRE, 1749, p. 88).
}

Ao longo de sua doutrina, Francisco José Freire (1749) alerta para a necessidade de que as imagens da fantasia sejam dirigidas pelo entendimento, pois, para ele, a fantasia poética seria como “[...] um cavalo mui fogoso, o qual para não ser desenfreado, é preciso, que se sujeite às regras da Arte" (FREIRE, 1749, p. 121). Sem a direção adequada do juízo, essas imagens seriam consideradas “cadáveres" e "monstruosas", pois não contribuem para a proporção, a ordem e a unidade que são os princípios da beleza poética.

Sendo assim, ao qualificar o engenho do herói-cômico como bizarro, Freire parece indicar que o contraste formado pela associação de heróis e personagens baixos, envolvidos por um motivo fútil, e a elocução própria das ações grandiosas de heróis e personagens virtuosos dos poemas épicos, assim como aqueles do trágico e do cômico, seria fruto de uma operação desregulada da fantasia, consequência de uma atuação deficiente do entendimento que, por "capricho", não submete a fantasia aos preceitos poéticos. 
Observe-se, portanto, que, embora o discurso de Silva Alvarenga aponte para sua conformidade com a doutrina poética de Francisco José Freire quanto ao fim utilitário da poesia, no cumprimento de sua faculdade civil, que se prova na incorporação de Sebastião José de Carvalho e Mello como argumento de $O$ Desertor, em conformidade com o apelo feito na dedicatória ao ministro na segunda edição da Arte Poética, o poeta esbarra na censura do próprio Freire ao poema herói-cômico.

Considerando isso, por mais que a obra do luso-brasileiro contemple o aspecto ético da doutrina, a opção pelo gênero em questão faria, então, com que ela não atendesse às recomendações do costume prescritas por Freire. Dessa forma, desajustado enquanto "arte fabricante", o poema herói-cômico de Alvarenga estaria em desacordo com o conceito de "perfeita e verdadeira poesia", cuja obrigação como arte seria, igualmente, instruir e deleitar, como se discutiu anteriormente.

Alvarenga prossegue o seu discurso trazendo uma lista de poemas herói-cômicos divididos entre "antigos e modernos". Como se sabe, o termo "herói-cômico" é utilizado pela primeira vez somente no século XVII. Segundo Ronald Polito, a origem do poema herói-cômico remonta às práticas letradas do século seiscentos, em que, ao valorizar o virtuosismo verbal, teria contribuído para o desenvolvimento de uma nova espécie de poesia que mescla em sua forma o burlesco e o épico. De acordo com o autor, foi o italiano Alessandro Tassoni (15651635), no poema La Secchia Rapita (1622), quem primeiro teria utilizado o termo:

O primeiro que empregou o termo herói-cômico (em italiano, eroicomico) foi Alessandro Tassoni, no poema La secchia rapita (1622) (O balde roubado), publicado em 1622, mas escrito em 1614 e 1615. O poema herói-cômico, ao menos na Itália, surge como reação ao poema épico-cavalheiresco, que prolifera a partir de Ariosto e de Tasso. O poema herói-cômico, pelo contrário, trata um sujeito ou uma matéria fúteis e ligeiros com tom solene e linguagem do poema épico, como já dissemos, de modo que do contraste entre o conteúdo e forma nasce o riso [...]. Insere-se na inclinação seiscentista e barroca por tudo que é grotesco, bizarro e dessacralizante (ALVARENGA, 2003, p. 22).

Para Silva Alvarenga, porém, a sua prática é muito mais antiga, cujas fontes remontariam aos poemas Margites, Batracomiomaquia e Culex. Sendo os dois primeiros atribuídos por ele a Homero e, o último, a Virgílio, esses poemas atestariam a antiguidade do gênero heróicômico. Quanto aos denominados como "modernos", o poeta cita Hudibras (1663-1678), de Samuel Butler (1612-1680), The Rape of the Lock (1712), de Alexander Pope (1688-1744) e Vert-Vert (1734), de Jean-Baptiste Gresset (1709-1777).

Por sua vez, para o poeta luso-brasileiro, esse conjunto de poemas poderia ser ainda dividido em, ao menos, duas vertentes: a dos que se fundamentariam nos preceitos da epopeia 
e a dos que omitiriam ou desprezariam tais fundamentos, possibilitando, segundo ele, a abertura de novos caminhos:

Uns sujeitaram o poema herói-cômico a todos os preceitos da Epopeia, e quiseram
que só se diferisse pelo cômico da ação, e misturaram o ridículo, e o sublime de tal
sorte, que servindo um de realce a outro, fizeram aparecer novas belezas em ambos
os gêneros. Outros omitindo, ou talvez desprezando algumas regras, abriram novos
caminhos à sua engenhosa fantasia, e mostraram disfarçada com inocentes
graciosidades a crítica mais insinuante, como M. Gresset no seu Ververt
(ALVARENGA, 2003, p. 73).

Silva Alvarenga não deixa explícito qual dessas vertentes teria sido o modelo para $O$ Desertor e, além do poema de Jean-Baptiste Gresset, não indica em qual delas se encaixariam os demais poemas herói-cômicos mencionados em sua lista.

De início, essa lista de poemas, especialmente os indicados como "antigos", pode ser compreendida, mais uma vez, como uma justificativa diante da censura da doutrina poética de Francisco José Freire em relação ao poema herói-cômico. Como se viu, no segundo livro de sua Arte Poética, Freire critica a tragicomédia, considerando-a um monstro na poesia por unir dois gêneros que considera antagônicos: a tragédia e a comédia. Ao encerrar sua argumentação, o autor faz a seguinte observação:

Poderíamos ser mais extensos neste assumpto; porém sobram os fundamentos, que apontamos, e talvez bastaria somente dizer, que os antigos sendo os Mestres da Poética, e os únicos exemplares, que se devem seguir, e venerar, não praticaram semelhante espécie de Poesia, considerando, que era monstruosa (FREIRE, 1749, p. 54-55).

Embora tenha se empenhando em demonstrar a incompatibilidade do trágico e do cômico na composição da tragicomédia, Freire considera que só o fato de não se ter entre os poetas antigos modelos dessa espécie de poesia já seria suficiente para condená-la. Diante disso, a lista de Silva Alvarenga, ao que parece, é mais uma tentativa de distanciar o herói-cômico do argumento de Freire quanto à composição mista da tragicomédia. Se, primeiramente, Alvarenga tenta demonstrar que, na junção do heroico e do cômico, não há a destruição mútua que há entre o riso e o terror na tragicomédia, com essa lista, o poeta busca demonstrar que o poema heróicômico, ao contrário, foi praticado pelos antigos, decorrendo de uma longa tradição.

Quanto aos poemas classificados como modernos, Silva Alvarenga parece querer indicar a filiação de $O$ Desertor à vertente que, segundo ele, omite e até despreza algumas regras da epopeia. Enquanto na primeira a mistura do sublime com o ridículo, segundo ele, realça as propriedades de ambas, propiciando "novas belezas", a omissão dessa segunda vertente 
estabeleceu novos caminhos para a "engenhosa fantasia" em direção da "crítica mais insinuante", como se vê no último parágrafo do discurso:

É desnecessário trazer à memória a autoridade, e o sucesso de tão ilustres Poetas para
justificar o Poema Herói-cômico, quando não há quem duvide que ele, porque imita,
move, e deleita: e porque mostra ridículo o vício, e amável a Virtude, consegue o fim
da verdadeira poesia (ALVARENGA, 2003, p. 73).

Estaria $O$ Desertor, portanto, não apenas emulando uma espécie de poesia cuja prática teria sido exercida por vários dos grandes poetas, o que conferiria autoridade ao gênero, mas também em consonância com o fim da poesia dos setecentos, conforme determinava a doutrina de Francisco José Freire, deleitando e, simultaneamente, ensinando, tendo Pombal como herói e argumento.

\section{Considerações finais}

Posto isso, o "Discurso sobre o poema herói-cômico" apresenta-se não como uma espécie de texto crítico às prescrições de Francisco José Freire, mas como uma justificativa que busca demonstrar a adequação de $O$ Desertor enquanto poema herói-cômico ao âmbito poético da doutrina, o que lhe conferiria legitimidade enquanto "verdadeira poesia". Sendo assim, é imprescindível partir da consideração de Silva Alvarenga quanto ao gênero para que seja possível analisar efetivamente a obra para além da superficialidade da ótica romântica de cunho nacionalista e desinteressada pela convenção.

\section{Referências}

ALVARENGA, Silva. O Desertor: poema herói-cômico: Organização, fixação do texto e notas (Ronald Polito) UNICAMP, 2003.

ARISTÓTELES. Poética. Tradução de Eudoro de Souza. In: Aristóteles II. São Paulo: Abril Cultural, 1984.

CANDIDO, Antonio. Formação da Literatura Brasileira. 5. ed., Belo Horizonte: Itatiaia, 1975.

FREIRE, Francisco José. Arte poética. Lisboa, Oficina Patriarcal de Francisco Luiz Ameno, 1748.

GENETTE, Gérard. Verossímil e motivação. In: BARTHES, Roland et alii. Literatura e semiologia. Tradução de Célia Neves Dourado. Petrópolis: Vozes, 1971 
PLATÃO. A República. 7. ed. Tradução de Maria Helena da Rocha Pereira. Lisboa: Fundação Calouste Gulbenkian, 1993.

SOUZA E SILVA, Joaquim Norberto. Obras poéticas. Rio de Janeiro: Garnier, 1864.

TEIXEIRA, Ivan. Mecenato pombalino e poesia neoclássica. São Paulo: Editora da Universidade de São Paulo, 1999.

Recebido em: 30/09/2019

Aceito para publicação em: 13/11/2019 